dr inż. Anna Dubel

AGH Akademia Górniczo-Hutnicza w Krakowie

Wydział Zarządzania

e-mail: adubel@zarz.agh.edu.pl

\title{
METODYKA OPRACOWYWANIA SCENARIUSZY WSPOMAGAJĄCYCH PODEJMOWANIE STRATEGICZNYCH DECYZJI W SEKTORZE GOSPODARKI WODNEJ
}

\section{METHODS OF SCENARIOS DEVELOPMENT FOR STRATEGIC DECISION MAKING IN WATER MANAGEMENT SECTOR}

\begin{abstract}
The aim of the paper is to present the method for strategic scenarios development in the water sector (accounting for climate change) in relation to other methods of scenario development of this type, to discuss the creation of alternative scenarios, their usefulness and possible uses, as well as the strengths and weaknesses of the scenario process to support the effective use of scenario methods in the future. The needs for scenario methods and their usefulness were presented. A review and classification of scenario methods related to strategic development issues of the water sector, including climate change, based on selected projects implemented in Poland and worldwide were conducted. The process of creating scenarios was discusses. The strengths and weaknesses of the process were identified and recommendations for the effective use of scenario methods in the future were presented.
\end{abstract}

Keywords: water management, scenarios, methods, strategy

JEL classification: Q01, Q54, Q15, Q24, R58, R52, J11, C53, D81

\section{Wstęp}

Omawiane scenariusze rozwoju definiowane są również jako wizje rozwoju lub długofalowe scenariusze strategiczne, z uwagi na analizowaną w nich perspektywę czasową (do 2030 lub do 2050). Są one uproszczonymi wizjami przyszłego rozwoju opracowanymi na podstawie spójnych założeń dotyczących 
kluczowych czynników wpływu i relacji między zmiennymi analizowanego systemu ${ }^{1}$. Tego typu scenariusze są stosowane dla wyjaśnienia i oswojenia niepewności związanej z przyszłymi trendami zmian analizowanych złożonych zjawisk. Są one użyteczną metodą, która zastosowana rygorystycznie, zgodnie ze sztuką i z uwzględnieniem ograniczeń, daje interesujące wyniki dla planowania strategicznego na różnych poziomach - od indywidualnego po strategie globalne. Na rysunku 1 przedstawiono relacje scenariuszy do innych metod analiz futurystycznych. Metody scenariuszowe stosowane są do analizy możliwego kształtowania się w przyszłości wskaźników, zmiennych, zjawisk, które cechuje znaczna złożoność i kompleksowość, niepozwalająca na prognozowanie lub prostą ekstrapolację obecnych trendów (np. systemy społeczno-ekonomiczne, powiązania sektorów energetycznego, wodnego i rolnictwa).

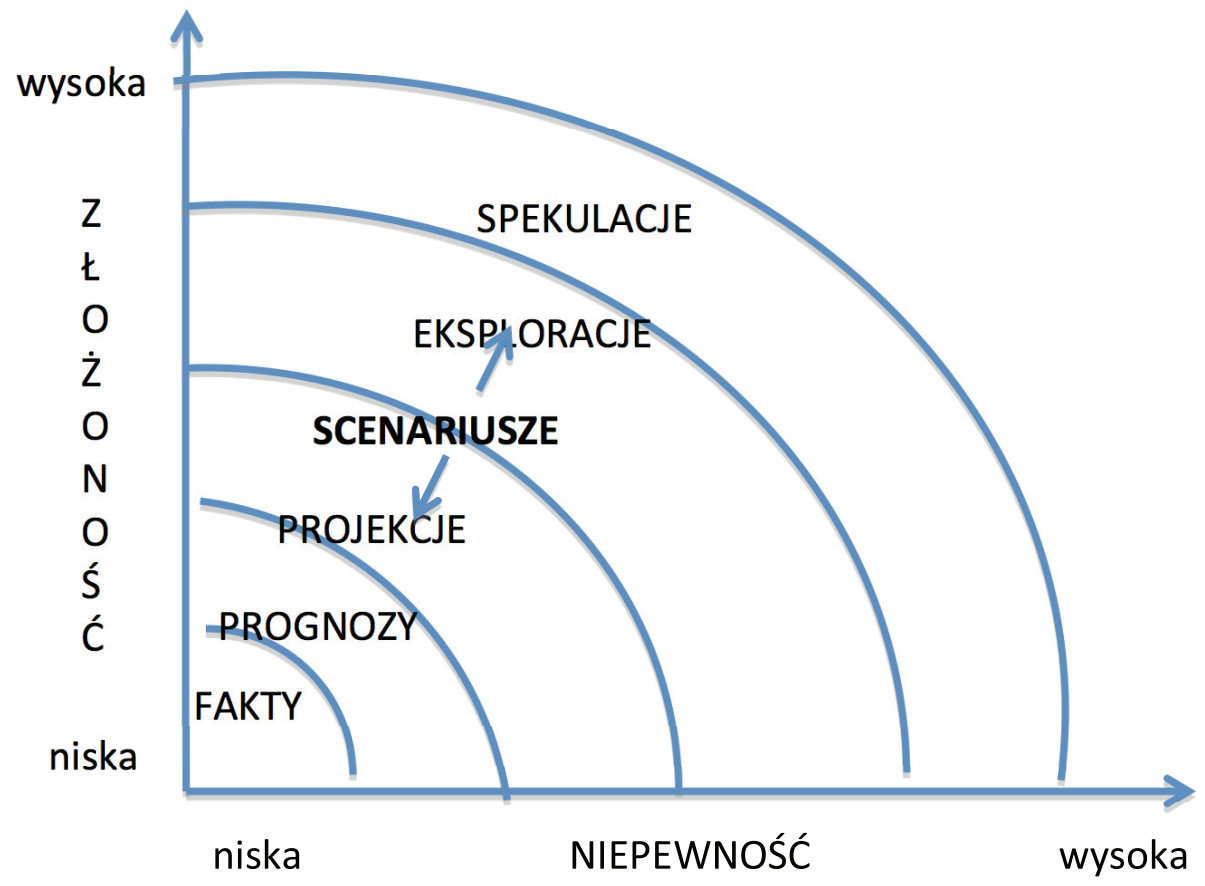

Rysunek 1. Miejsce scenariuszy pośród innych metod analiz futurystycznych

Źródło: opracowanie własne na podstawie: K. Kok, Methods for developing multiscale participatory scenarios: insights from Southern Africa and Europe, „Ecology and Society” 2007, vol. 12, s. 8 .

${ }^{1}$ M.D.A. Rounsevell, M.J. Metzge, Developing qualitative scenario storylines for environmental change assessment, „Wiley Interdisciplinary Reviews: Climate Change” 2010, vol. 1, no. 4, s. 606-619. 
W artykule przedstawiono metody opracowywania scenariuszy wspomagających podejmowanie strategicznych decyzji w sektorze gospodarki wodnej, $\mathrm{z}$ uwzględnieniem zmian klimatycznych, w relacji do innych metod scenariuszowych. Na przykładach omówiono proces tworzenia scenariuszy, ich użyteczność i możliwe zastosowania, a także mocne strony i ograniczenia procesu pod kątem efektywnego stosowania metod scenariuszowych w przyszłości. Na bazie wybranych projektów dokonano przeglądu i klasyfikacji implementowanych na świecie i w Polsce metod scenariuszowych dotyczących strategicznych kwestii rozwojowych sektora gospodarki wodnej, z uwzględnieniem zmian klimatycznych. Zidentyfikowano słabe i mocne strony procesu tworzenia tego typu scenariuszy oraz przedstawiono rekomendacje dla efektywnego stosowania metod scenariuszowych w przyszłości.

\section{Materiały i metodyka badań}

Dokonano przeglądu obszernej literatury naukowej, a także studiów, analiz oraz dokumentów programowych i strategicznych w zakresie metod opracowywania scenariuszy (długofalowych wizji rozwoju) i ich wyników. Na podstawie praktycznych doświadczeń autorki z prowadzenia tego typu procesów scenariuszowych w kilku projektach naukowych (SCENES, KLIMAT, CHASE-PL) i analizy przypadków implementacji metod scenariuszowych określono użyteczność, mocne strony i ograniczenia procesu oraz rekomendacje dla efektywnego stosowania metod scenariuszowych.

\section{Wyniki badań}

Przegląd stosowanych metod scenariuszowych pozwala na dokonanie następujących klasyfikacji:

- ze względu na skalę: globalne, panregionalne, lokalne (np. państwa, mniejsze jednostki administracyjne, zlewnie);

- ze względu na zakres tematyczny: społeczno-ekonomiczne, sektorowe (np. energetyka, ekosystemy, gospodarka wodna, klimat), dedykowane dla poszczególnych podmiotów (np. firm);

- ze względu na rodzaj stosowanych metod i otrzymanych wyników: jakościowe, ilościowe, quasi-ilościowe, mieszane;

- ze względu na sposób opracowywania z udziałem uczestników procesu tworzenia scenariuszy: eksperckie, partycypacyjne;

- ze względu na okres analizy: krótko- i długofalowe. 
Geneza planowania scenariuszowego sięga lat 40. XX w. i analiz wykorzystania technologii militarnych Hermana Khana (USA) oraz studiów futurologicznych Gastona Bergera (Francja). Metody scenariuszowe były rozwijane w latach 60 . przez organizacje i agendy rządowe do symulacji możliwych rozwojów sytuacji politycznych i konfliktowych. W biznesie znalazły zastosowanie na początku lat 70. i okazały się bardzo skuteczne, gdyż dzięki opracowanym scenariuszom (wizjom przyszłości) menadżerowie Shell Group trafnie dobierali strategie w reakcji na zmiany na rynku ropy naftowej. Scenariusze globalne w zakresie zintegrowanego podejścia do środowiska zostały opracowane przez UNEP w ramach Global Environmental Outlook (GEO-3 2004², GEO-4 2007³, GEO-5 20124). Ekosystemy i usługi ekosystemów zostały poddane analizie w ramach Oceny Milenijnej (Millennium Ecosystem Assessment 2005), a perspektywiczna analiza środowiskowa zmian w użytkowaniu gruntów w Europie z analizą funkcji ekosystemów została przeprowadzona w scenariuszach PRELUDE ${ }^{5}$ Europejskiej Agencji Środowiska. Natomiast scenariusze dotyczące klimatu i emisji gazów cieplarnianych są rozwijane przez Międzyrządowy Zespół ds. Zmian Klimatu (Intergovernmental Panel on Climate Change - IPCC) w kolejnych raportach publikowanych w latach 2000, 2007, 2014. Ponadto, globalne scenariusze są tworzone przez Global Scenario Group ${ }^{6}$, IIASA (World Water Scenarios) czy World Energy Council (World Energy Scenarios). W scenariuszach globalnych najnowszej generacji różnorodne możliwe wizje rozwoju społeczno-ekonomicznego w przyszłości, z uwzględnieniem polityk klimatycznych, są przedstawiane w postaci tzw. ścieżek społeczno-ekonomicznych (Shared Socio-economic Pathways - SSPs), które są powiązane ze scenariuszami emisyjnymi (Representative Concentration Pathways - RCPs). W trwającym projekcie IMPRESSIONS ${ }^{7}$ zaprezentowano ich analizę.

Poniżej zostaną przedstawione projekty mogące wspomóc podejmowanie strategicznych decyzji w sektorze gospodarki wodnej, wykorzystujące metody scenariuszowe i narracje.

W projekcie SCENES (Water Scenarios for Europe and Neighbouring States, realizowanym w latach 2007-2010, finansowanym z 7.PR) zastosowano podejście Story-and-Simulation (SAS) ${ }^{8}$. Łączy ono metody jakościowe (panele eksperckie)

2 J. Potting, J. Bakkes (eds), The GEO-3 Scenarios 2002-2032: Quantification and analysis of environmental impacts. UNEP/DEWA/RS.03-4 and RIVM 402001022, UNEP/RIVM, 2004.

3 GEO-4. 2007. Environment for development, UNEP, 2007.

${ }^{4}$ GEO-5. 2012. Environment for the future we want, UNEP 2012.

5 www.eea.europa.eu/themes/scenarios/prelude (dostęp: 1.06.2016).

${ }^{6}$ www.gsg.org (dostęp: 1.06.2016).

${ }^{7}$ K. Kok i in., Evaluation of existing climate and socio-economic scenarios. EU FP7 IMPRESSIONS Project Deliverable D2.1, 2015.

8 J. Alcamo, Scenarios as Tools for International Environmental Assessments. Experts' Corner Report: Prospects and Scenarios No. 5, European Environment Agency, Copenhagen 2001, Environmental Issue Report, No. 24; J. Alcamo, The SAS approach: Combining qualitative and quantitative 
z metodami ilościowymi (modelowanie). W projekcie przetestowano metodę opartą na czterech warsztatach z udziałem ekspertów, integrującą metody jakościowe, tj. tworzenie narracji i przyczynowo-skutkowe modele koncepcyjne (ang. causal loop diagrams) ${ }^{9}$, metodę analizy wstecznej (ang. backasting $)^{10}$, modele semi-ilościowe (ang. fuzzy cognitive maps) ${ }^{11}$ oraz model WaterGAP ${ }^{12}$. Podejście to zostało zaimplementowane w projekcie SCENES, również w warunkach polskich ${ }^{13}$. Do analiz przyczynowo-skutkowych i powiązań pomiędzy zmiennymi może być również stosowana analiza DPSIR.

W projekcie KLIMAT $^{14}$ zastosowano podobne podejście, bazując na wybranych scenariuszach emisyjnych, opracowano w metodyce podobnej do SAS rozwojowe scenariusze społeczno-ekonomiczne, na podstawie których wnioskowano na temat przyszłego wykorzystania zasobów wodnych. Na jego wynikach bazował projekt KLIMADA ${ }^{15}$, na podstawie którego stworzono strategię adaptacji Polski do zmian klimatu ${ }^{16}$.

knowledge in environmental scenarios, [w:] J. Alcamo (ed.), Environmental futures: the practice of environmental scenario analysis. Developments in Integrated Environmental Assessment, vol. 2, Elsevier, Amsterdam 2009, s. 123-150.

9 A. Dubel i in., Final Draft of All Causal Loop Diagrams, Deliverable 2.8 of the SCENES Project, International Institute for Applied Systems Analysis, Laxenburg 2010.

${ }^{10} \mathrm{~K}$. Kok i in., Combining participative backcasting and exploratory scenario development: Experiences from the SCENES project, „Technological Forecasting and Social Change” 2011, vol. 78, no. 5 , s. $835-851$.

${ }^{11}$ M. van Vliet i in., Description of methods, their goals and their possible use in SCENES scenario development, Deliverable 2.1, Wageningen University, Wageningen 2007.

${ }_{12}$ Kok K. i in., Combining participative...

${ }_{13}$ M. Piniewski, T. Okruszko, M.C. Acreman, Environmental water quantity projections under market-driven and sustainability-driven future scenarios in the Narew basin, Poland, „Hydrological Sciences Journal” 2014, DOI: 10.1080/02626667.2014.888068; M. Giełczewski i in., How can we involve stakeholders in the development of water scenarios? Narew River Basin case study, „Journal of Water and Climate Change" 2011, vol. 2, no. 2-3, s. 166-179.

14 „Wpływ zmian klimatu na gospodarkę, środowisko i społeczeństwo”, projekt realizowany w latach 2008-2012, finansowany w ramach POIG; J. Kindler, A. Dubel, Wizja potrzeb wodnych polski do 2050 roku - analiza istniejacych dokumentacji prognostycznych i dyskusja możliwych kierunków rozwoju (Ekspertyza projektu KLIMAT: „Wpływ zmian klimatu na społeczeństwo, środowisko i gospodarkę”, zadanie 3: „Zrównoważone gospodarowanie wodą, zasobami geologicznymi i leśnymi kraju”), IMGW, Kraków 2010; A. Dubel, Opracowanie scenariuszy rozwoju gospodarki wodnej w Polsce dla scenariuszy emisyjnych A2, B1, A1B (Ekspertyza projektu KLIMAT: „Wpływ zmian klimatu na społeczeństwo, środowisko i gospodarkę”, zadanie 3: „Zrównoważone gospodarowanie wodą, zasobami geologicznymi i leśnymi kraju”), IMGW, Kraków 2009; W. Maciejewski, T. Walczykiewicz (red.), Zrównoważone gospodarowanie zasobami wodnymi oraz infrastruktura hydrotechniczna w świetle prognozowanych zmian klimatycznych, IMGW, Warszawa 2012.

15 „Opracowanie i wdrożenie strategicznego planu adaptacji dla sektorów i obszarów wrażliwych na zmiany klimatu", projekt finansowany przez NFOŚiGW.

${ }^{16}$ Strategiczny plan adaptacji dla sektorów i obszarów wrażliwych na zmiany klimatu do roku 2020 z perspektywą do 2030, Ministerstwo Środowiska, Warszawa 2013. 
W projekcie CHASE-PL ${ }^{17}$ zastosowano podejście SAS (dwa warsztaty eksperckie, model SWAT) do opracowania długofalowych (do roku 2050) scenariuszy (wizji) strategicznych rozwoju w Polsce sektorów mających wpływ na zasoby wodne, takich jak rolnictwo, leśnictwo, energetyka czy sektor komunalny.

Przegląd projektów 7.PR EU pozwala stwierdzić, iż metody scenariuszowe są stosowane $\mathrm{np}$. w projektach $\mathrm{z}$ tematyki bezpieczeństwa społecznego, dotyczącego również katastrof naturalnych, np. SICMA ${ }^{18}$, SNOWBALL ${ }^{19}$, EVACUATE $^{20}$, czy też w projektach dotyczących zarządzania zasobami, z uwzględnieniem zmian klimatu. Przykładowo do analiz w projektach MARS ${ }^{21}$ i GLOBAQUA ${ }^{22}$ wybrano scenariusze bazujące na SSPs i RCPs, z wyodrębnieniem narracji (ang. storylines), kluczowych zmiennych oraz z uwzględnieniem przyjętych założeń zmian ich trendów w przyszłości (tj. silny/średni/niewielki wzrost lub spadek).

Zastosowanie podobnych do omawianych metod scenariuszowych do podejmowania decyzji strategicznych i planowania polityk jest aplikowane w różnych regionach świata, m.in. w Południowo-Wschodniej Azji2 ${ }^{23}$.

Rozpowszechnionym narzędziem planowania strategicznego, opartego o partycypacyjne tworzenie wizji rozwoju, są również studia i analizy typu foresight, które mogą stanowić źródło informacji dla scenariuszy rozwojowych. Przykładem takiego badania był Narodowy Program Foresight „Polska 2020”.

Innym zastosowaniem scenariuszy jest modelowanie scenariuszowe, którego przykładem może być aplikacja modelu SWAT w zlewni Redy do kwantyfikacji efektów przyszłych zmian klimatu (do 2050 roku), użytkowania terenu i zarządzania, definiowanych w postaci alternatywnych scenariuszy ${ }^{24}$.

Z kolei planowanie scenariuszowe jest uznanym narzędziem planowania strategicznego, które zmniejsza niepewność w podejmowaniu decyzji dzięki braniu

17 „Climate Change Impact Assessment on Selected Sectors in Poland”, projekt realizowany w latach 2014-2016 w ramach Norweskiego Mechanizmu Finansowego; A. Dubel, Dtugofalowe scenariusze strategicznego rozwoju w Polsce sektorów majacych wpływ na zasoby wodne, Centrum Rozwiązań Systemowych, Kraków 2015; „Simulation of crisis management activities”, www.sicmaproject.eu (dostęp: 1.06.2016).

18 „Simulation of crisis...”

19 „Lower the impact of aggravating factors in crisis situations thanks to adaptive foresight and decision-support tools", www.ismb.it/en/node/2034 (dostęp: 1.06.2016).

20 „A holistic, scenario-independent, situation-awareness and guidance system for sustaining Active Evacuation Route for large crowds", http://fortress-project.eu (dostęp: 1.06.2016).

${ }^{21}$ „Managing aquatic ecosystems and water resources under multiple stress”, www.mars-project.eu (dostęp: 1.06.2016).

22 „Managing the effects of multiple stressors on aquatic ecosystems under water scarcity”, projekt realizowany w latach 2014-2019, w ramach 7.PR UE.

${ }^{23}$ D. Mason-D'Croza i in., Multi-factor, multi-state, multi-model scenarios: Exploring food and climate futures for Southeast Asia, „Environmental Modelling \& Software” 2016, vol. 83, s. $255-270$.

${ }^{24}$ M. Piniewski i in., Climate Change and Agricultural Development: Adapting Polish Agriculture to Reduce Future Nutrient Loads in a Coastal Watershed, „Ambio” 2014, vol. 43, no. 5, s. 644-660. 
pod uwagę zakresu potencjalnych okoliczności ${ }^{25}$. Podstawowymi elementami metody są: identyfikacja czynników wpływu, kluczowych niepewności oraz punktów zwrotnych w kreatywnej narracji scenariuszy.

Analiza scenariuszowa (ang. scenario analysis) służy identyfikacji różnych możliwych „przyszłości” dla analizowanych kwestii, problemów czy obszarów ${ }^{26}$. Na bazie scenariuszy firmy oraz władze mogą tworzyć strategie i plany. Analiza scenariuszowa jest również wykorzystywanym narzędziem w badaniach z dziedziny zarządzania. Można przeprowadzić ją w opisanych poniżej trzech krokach ${ }^{27}$ :

1. Identyfikacja kluczowych czynników wpływających na przedmiot analiz i określenie ich kształtowania się w przyszłości, dyskusja nad tymi czynnikami w gronie ekspertów, menedżerów czy decydentów.

2. Zdefiniowanie czterech alternatywnych scenariuszy i opracowanie narracji (ang. storylines) na podstawie projekcji przyszłych charakterystyk kluczowych czynników wpływu.

3. Opracowanie wniosków z analizy scenariuszy i rekomendacji dotyczących przedmiotu analiz dla określonych interesariuszy (np. decydentów, firm, gospodarstw domowych itp.).

W podejściu Story-and-Simulation proces tworzenia scenariuszy dla opracowania wizji strategicznych można zdefiniować w następujących krokach:

1. Zdefiniowanie zakresu (tematyki, problemu, ram przestrzennych i czasowych), dla którego będą tworzone scenariusze.

2. Określenie dwóch osi niepewności, które definiują cztery scenariusze.

3. Przyjęcie podstawowych założeń dotyczących przyszłości (narracja).

4. Kwantyfikowanie wybranych zmiennych przez ekspertów za pomocą logiki rozmytej (ang. fuzzy logic) i modelowanie zmiennych za pomocą metod quasi-ilościowych i ilościowych.

5. Scenariusze ilościowe stanowią informację zwrotną dla multidyscyplinarnego panelu ekspertów.

Iteracje powyższego procesu mają również walor edukacyjny dla uczestników procesu opracowania scenariuszy, którymi są zazwyczaj:

- zespół opracowujący scenariusze (odpowiedzialny za metodykę i koordynację prac nad tworzeniem scenariuszy),

- panel ekspertów (eksperci z wielu dziedzin zapewniający wkład merytoryczny $\mathrm{w}$ procesie opracowywania scenariuszy),

- zespół do spraw modelowania (kwantyfikujący scenariusze).

${ }^{25}$ M. Muskat, D. Blackman, B. Muskat, Mixed Methods: Combining Expert Interviews, Cross-Impact Analysis and Scenario Development, „The Electronic Journal of Business Research Methods” 2010, vol. 10, no. 1, s. 9-21.

${ }^{26}$ N. Hagemann i in., Possible Futures towards a Wood-Based Bioeconomy: A Scenario Analysis for Germany, „Sustainability” 2016, vol. 8, no. 1, s. 98.

${ }^{27}$ Tamże. 
Podczas warsztatów eksperckich i w badaniach typu foresight stosowane są m.in. metoda delficka czy nominalna technika grupowa. Metoda delficka jest kwestionariuszową metodą zbierania opinii od ekspertów na temat zdefiniowanych problemów dotyczących hipotetycznego rozwoju przyszłych zdarzeń i twórczego ich rozwiązywania. Nominalna technika grupowa ${ }^{28}$ jest ustrukturyzowaną techniką burzy mózgów wykorzystywaną do grupowego podejmowania decyzji i kreatywnego rozwiązywania problemów.

Najistotniejsze brane pod uwagę czynniki wpływu (ang. key driving forces) na analizowane zmienne i zjawiska zależą od zdefiniowanego zakresu i rodzaju tematyki. Przykładowo dla zmiennych z dziedziny gospodarki wodnej zazwyczaj są one ujmowane w kategoriach takich, jak:

- aspekty społeczne: presja i oczekiwania społeczne, wzrost populacji, migracje; wzrost i rozwój ekonomiczny, wpływający na zmiany użytkowania terenu; rozwój technologiczny; rozwój sektorów wykorzystujących zasoby wodne (CHASE-PL);

- społeczeństwo, ekonomia, energia, środowisko, zarządzanie wodą (GLOBAQUA);

- wzrost gospodarczy, różnice w poziomie bogactwa, rozwój społeczny, rozwój w aspekcie ochrony środowiska, populacja, rozwój technologiczny, rozwój rolnictwa, rozwój leśnictwa, rozwój przemysłu i usług, rozwój gospodarki energetycznej (KLIMAT).

Dla scenariuszy dotyczących gospodarki wodnej i kształtowania się zasobów wodnych w przyszłości w szczególności przydatne jest analizowanie trendów zmian zachodzących w sektorach takich, jak: rolnictwo, rozwój miast, budownictwo, przemysł, energetyka, leśnictwo, ochrona przyrody czy transport.

W artykule nie jest możliwe, ze względów praktycznych, zaprezentowanie wyników, jakie dają metody scenariuszowe, ani ich bezpośrednie porównanie, ze względu na dużą dowolność w sposobach prowadzenia procesów scenariuszowych i możliwość użycia szerokiej gamy różnorodnych metod, a także inaczej zdefiniowane cele, zakres scenariuszy i analizowane problemy oraz odmienne założenia i konstrukcje procesów prowadzące do różnych wyników. Porównywanie wyników nie byłoby też zasadne z uwagi na to, że scenariusze opracowuje się w konkretnych celach i w różnej skali. Równocześnie scenariusze opracowane przez IPCC lub w innych wspomnianych projektach są dalej rozwijane w kolejnych aplikacjach w skali globalnej, panregionalnej czy w innych skalach, np. zlewni ${ }^{29}$.

${ }^{28}$ A.L. Delbecq, A.H. VandeVen, A Group Process Model for Problem Identification and Program Planning. „Journal of Applied Behavioural Science” 1971, vol. 7, s. 466-91; A. Lasut, Creative Thinking and Modelling for the Decision Support in Water Management, FEEM Working Paper (Nota di Lavoro 81.2005), http://ssrn.com/abstract=740293 (dostęp: 15.06.2016).

${ }^{29} \mathrm{M}$. Giełczewski i in., How can we involve stakeholders in the development of water scenarios? Narew River Basin case study, „Journal of Water and Climate Change” 2011, vol. 2, no. 2-3, s. $166-179$. 
Na rysunkach 2, 3 i 4 zaprezentowano wybrane przykłady zdefiniowanych scenariuszy na podstawie wyróżnienia osi niepewności.

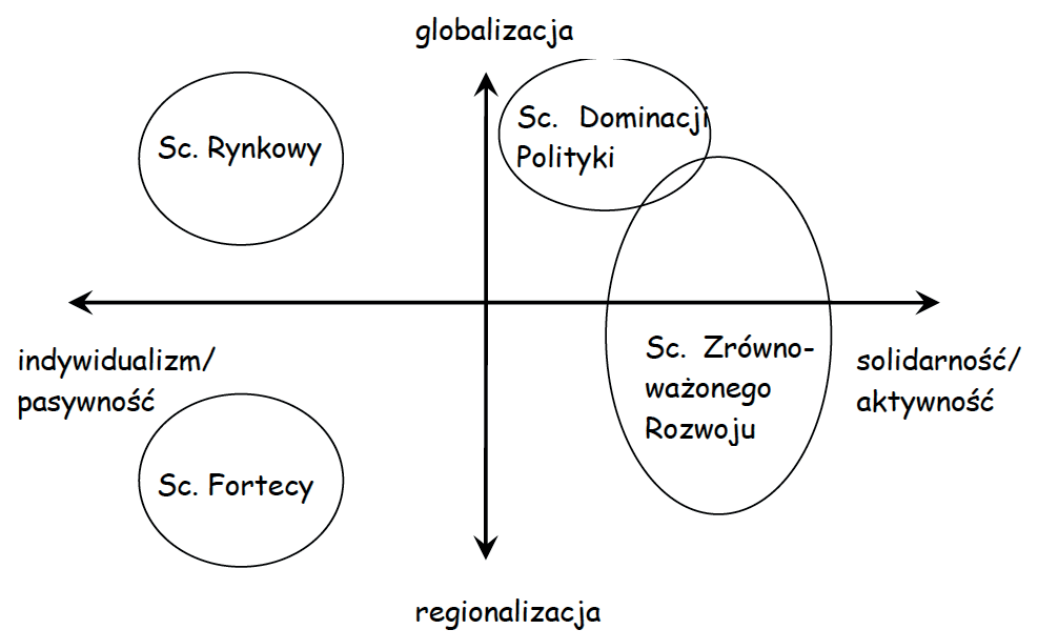

Rysunek 2. Scenariusze zdefiniowane w projekcie SENES

Źródto: opracowanie wtasne na podstawie: M. van Vliet i in., Description of methods, their goals and their possible use in SCENES scenario development, Deliverable 2.1, Wageningen University, Wageningen 2007.

Ten sam rodzaj niepewności był uwzględniany również w scenariuszach: GEO-3, GEO-4, SRES (IPCC), OECD, ATEAM, EURalis.

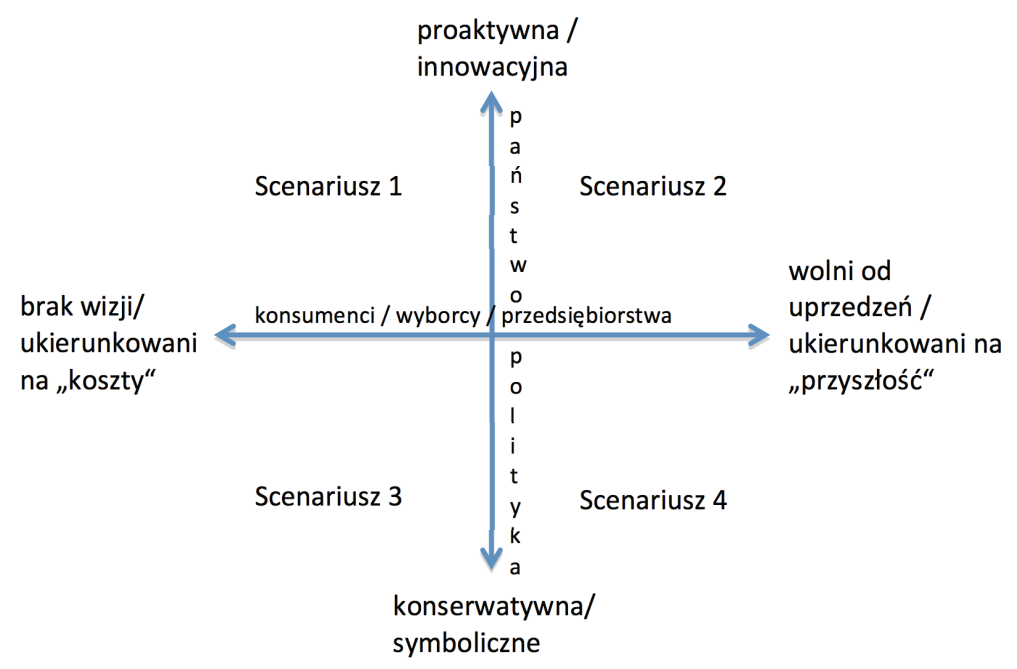

Rysunek 3. Scenariusze zdefiniowane w BioEconomic Cluster

Źródlo: opracowanie własne na podstawie: N. Hagemann i in., Possible Futures towards a Wood-Based Bioeconomy: A Scenario Analysis for Germany, ,, Sustainability” 2016, vol. 8, no. 1, s. 98. 


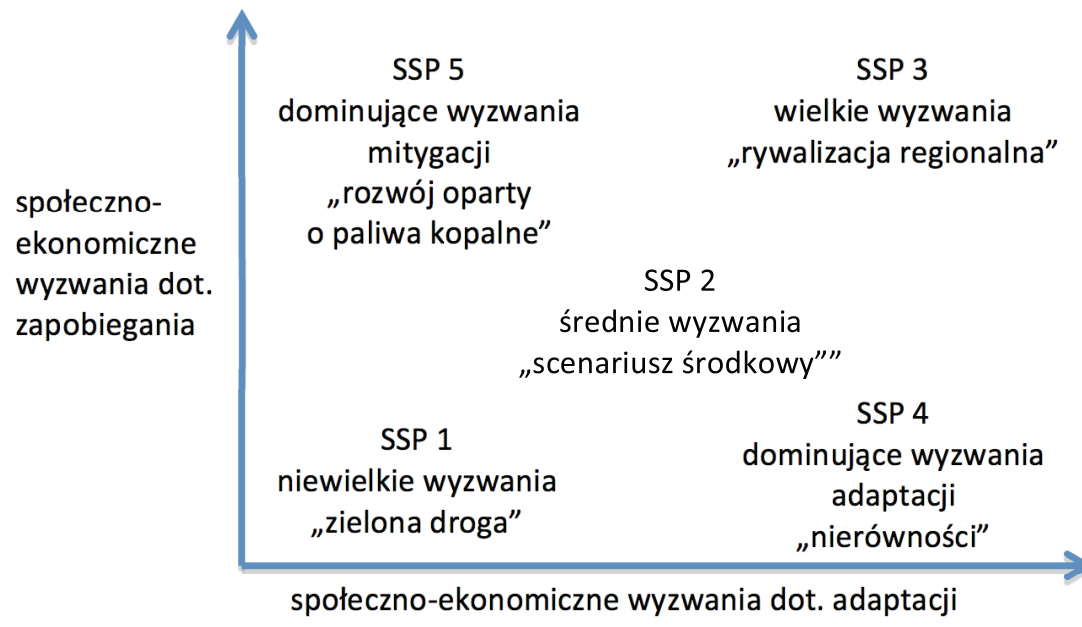

Rysunek 4. Zdefiniowane ścieżki społeczno-ekonomiczne (SSPs)

Źródto: opracowanie własne na podstawie: B.C. O'Neill i in., The roads ahead: Narratives for shared socioeconomic pathways describing world futures in the 21st century, ,, Global Environ. Change” 2015, DOI: 10.1016/j.gloenvcha.2015.01.004.

Autorka zauważyła podobieństwa w przejętych założeniach scenariuszy SSPs i Scenes (GEO-4, etc.): SSP 1 odpowiada Sc. Zrównoważonego Rozwoju, SSP3 - Sc. Fortecy, a SSP5 - Sc. Rynkowemu. Pozostałe scenariusze SSPs nie mają bezpośrednich odpowiedników.

Scenariusze są opracowywane w ramach badań, studiów i analiz naukowych lub przez firmy. Procesy scenariuszowe są czasochłonne i zasobochłonne, zwłaszcza jeśli w celu podniesienia jakości wyników prowadzone są z udziałem wielu ekspertów lub interesariuszy (w sposób partycypacyjny). Stąd ważne jest zdefiniowanie przed implementacją procesu ich celowości i użyteczności. Uzyskane wyniki alternatywnych możliwości rozwoju sytuacji w przyszłości mogą być wykorzystane do przygotowania się na różne, nawet niewygodne, scenariusze przyszłości, jak pokazują to wyniki projektu Scenes $^{30}$. Ponadto, rezultaty wskazujące na konkretne problemy (przykładowo według szacunków ONZ do 2050 r. dwóm miliardom ludzi będą groziły poważne w skutkach powodzie) pozwalają podjąć odpowiednio wcześniej działania zapobiegające lub przygotowawcze.

${ }^{30}$ O. Zhovtonog i in., New planning technique to master the future of water on local and regional level in Ukraine, ,Journal of Water and Climate Change” 2011, vol. 2, no. 2-3, s. 189-200; A. Lasut $\mathrm{i}$ in., Review of regional and pilot area consultations and consistency of scenario development approaches, SCENES Deliverable 2.3, International Institute for Applied Systems Analysis (IIASA), Laxenburg 2008; K. Kok i in., First draft of pan-European storylines - results from the second pan-European stakeholder workshop, SCENES Deliverable 2.6, Wageningen University, Wageningen 2009. 
Niektóre metody scenariuszowe, np. tworzenie wizji czy backcasting, są wykorzystywane w praktyce biznesowej i są promowane jako metody wspierające transformację w kierunku zrównoważonego rozwoju, niskoemisyjnej gospodarki oraz innowacyjnych sposobów adaptacji i zapobiegania zmianom klimatu dzięki temu, że promują kreatywne rozwiązania i strategie ${ }^{31}$, jak np. projekt „Room for the river” realizowany w Królestwie Niderlandów. Ponadto, jak wskazano, firma Shell Group uzyskała dzięki analizie scenariuszowej przewagę konkurencyjną.

Scenariusze dotyczące strategicznych kwestii rozwojowych pozwalają na symulację skutków wystąpienia podstawowych założeń dotyczących kluczowych niepewności. Myślenie w kategoriach scenariuszy ma wartość edukacyjną dla ekspertów, menadżerów i decydentów biorących udział w procesie. Dzięki analizie powiązań między kluczowymi zmiennymi ułatwia im zrozumienie relacji wewnątrz analizowanego systemu i jego powiązań z otoczeniem.

Zalety i ograniczenia scenariuszy należy rozpatrywać w relacji do realistycznych oczekiwań względem tej metody. Do jej zalet należą: możliwość systematycznej analizy kompleksowych kwestii, tworzenie narracji pozwalających na zrozumienie relacji przyczynowo-skutkowych, wymiana myśli, wzajemne uczenie się i efekty synergii ze wspólnej pracy ekspertów z wielu dziedzin, łączenie modeli jakościowych i ilościowych - wszystko to pozwala na weryfikację hipotez modelami ilościowymi oraz ekspercką weryfikację wyników modelowania. Natomiast wśród ograniczeń należy wskazać: bardzo subiektywny charakter wyników, ich wrażliwość na skład zespołu (konieczna jest dywersyfikacja specjalistów), trudności w konceptualizacji złożonych systemów i w precyzyjnym określeniu siły wzajemnych wpływów powiązanych zmiennych w kompleksowych systemach.

Równocześnie jakość uzyskanych wyników zależy od właściwego sposobu przeprowadzenia procesu, podczas którego należy zwrócić uwagę m.in. na:

- profesjonalne przeprowadzenie paneli lub innych metod eksperckich lub partycypacyjnych, w tym zapewnienie odpowiedniego zakresu ekspertyzy,

- skuteczne wykorzystanie ekspertyzy poprzez zapewnienie aktywnego i zbalansowanego udziału ekspertów z wielu dziedzin,

- stymulację kreatywnego myślenia o przyszłych trendach w rygorze logiki wynikającej jedynie z przyjętych założeń, w oderwaniu od aktualnych trendów. Na podstawie praktyki i analizy przypadków implementacji metod scenariuszowych do najważniejszych rekomendacji dla efektywnego stosowania metod scenariuszowych w przyszłości można zaliczyć:

- zdefiniowanie odbiorców wyników przeprowadzonego procesu scenariuszowego i celu jego prowadzenia,

${ }^{31}$ L. Sterrenberg i in., Transition thinking and System Innovation. Theoretical notions and application, Pioneers into Practice Mentoring Programme, Climate-KIC, Netherlands 2014. 
- precyzyjne określenie zakresu analizy scenariuszowej, z klarownym wyodrębnieniem analizowanych zmiennych oraz zewnętrznych czynników wpływu,

- wiarygodne i oparte na metodach jakościowych i ilościowych określenie powiązań pomiędzy zmiennymi.

\section{Podsumowanie}

Metody scenariuszowe to bardzo różnorodna grupa metod obejmująca analizy warunkowe, złożone procesy tworzenia alternatywnych wizji analizowanych kwestii w przyszłości czy kompleksowe procesy partycypacyjne z wykorzystaniem studiów typu foresight.

Scenariusze pozwalają na ujęcie kompleksowych i wielowymiarowych problemów, a podejście jakościowe i ilościowe wzajemnie się uzupełniają w wyjaśnianiu niepewności dotyczących możliwego rozwoju analizowanych zjawisk i systemów w przyszłości.

Przy niepewności dotyczącej zmian klimatycznych oraz kosztów adaptacji i zapobiegania tym zmianom alternatywne wizje rozwoju pozwalają na lepsze przygotowanie do wyzwań przyszłości.

Obszerna literatura naukowa w tym zakresie wskazuje na duże zainteresowanie tematem - zauważalny jest intensywny rozwój tych metod w ostatnich latach. Są one udoskonalane i ewoluują w kolejnych aplikacjach.

\section{Bibliografia}

Alcamo J., The SAS approach: Combining qualitative and quantitative knowledge in environmental scenarios, [w:] J. Alcamo (ed.), Environmental futures: the practice of environmental scenario analysis. Developments in Integrated Environmental Assessment, vol. 2, Elsevier, Amsterdam 2009, s. 123-150.

Alcamo J., Scenarios as Tools for International Environmental Assessments. Experts' Corner Report: Prospects and Scenarios No. 5, European Environment Agency, Copenhagen 2001, Environmental Issue Report, No. 24.

Delbecq, A.L., VandeVen A.H. 1971. A Group Process Model for Problem Identification and Program Planning. Journal of Applied Behavioural Science, VII (July/August, 1971), 466-491.

Dubel A., Dlugofalowe scenariusze strategicznego rozwoju w Polsce sektorów mających wplyw na zasoby wodne, Centrum Rozwiązań Systemowych, Kraków 2015.

Dubel A., Opracowanie scenariuszy rozwoju gospodarki wodnej w Polsce dla scenariuszy emisyjnych $A 2, B 1, A 1 B$ (Ekspertyza projektu KLIMAT: „Wpływ zmian klimatu na społeczeństwo, środowisko i gospodarkę”, zadanie 3: „Zrównoważone gospodarowanie wodą, zasobami geologicznymi i leśnymi kraju”), IMGW, Kraków 2009.

Dubel A. i in., Final Draft of All Causal Loop Diagrams, Deliverable 2.8 of the SCENES Project, International Institute for Applied Systems Analysis, Laxenburg 2010. 
GEO-4. 2007. Environment for development, UNEP 2007.

GEO-5. 2012. Environment for the future we want, UNEP 2012.

Giełczewski M. i in., How can we involve stakeholders in the development of water scenarios? Narew River Basin case study, ,Journal of Water and Climate Change” 2011, vol. 2, no. 2-3, s. $166-179$.

Hagemann N. i in., Possible Futures towards a Wood-Based Bioeconomy: A Scenario Analysis for Germany, „Sustainability” 2016, vol. 8, no. 1.

Kindler J., Dubel A., Wizja potrzeb wodnych polski do 2050 roku - analiza istniejacych dokumentacji prognostycznych i dyskusja możliwych kierunków rozwoju (Ekspertyza projektu KLIMAT: „Wpływ zmian klimatu na społeczeństwo, środowisko i gospodarkę”, zadanie 3: „Zrównoważone gospodarowanie wodą, zasobami geologicznymi i leśnymi kraju”, IMGW, Kraków 2010.

Kok K., Methods for developing multiscale participatory scenarios: insights from Southern Africa and Europe, „Ecology and Society” 2007, vol. 12.

Kok K. i in., Combining participative backcasting and exploratory scenario development: Experiences from the SCENES project, „Technological Forecasting and Social Change” 2011, vol. 78 , no. 5 .

Kok K. i in., Evaluation of existing climate and socio-economic scenarios, EU FP7 IMPRESSIONS Project Deliverable D2.1, 2015.

Kok K. i in., First draft of pan-European storylines - results from the second pan-European stakeholder workshop. SCENES Deliverable 2.6, Wageningen University, Wageningen 2009.

Lasut A. i in., Review of regional and pilot area consultations and consistency of scenario development approaches, SCENES Deliverable 2.3, International Institute for Applied Systems Analysis (IIASA), Laxenburg 2008.

Mason-D'Croza D. i in., Multi-factor, multi-state, multi-model scenarios: Exploring food and climate futures for Southeast Asia, „Environmental Modelling \& Software” 2016, vol. 83.

Muskat M., Blackman D., Muskat B., Mixed Methods: Combining Expert Interviews, Cross-Impact Analysis and Scenario Development, „The Electronic Journal of Business Research Methods” 2012, vol. 10 , no. 1.

O'Neill, B.C. i in., The roads ahead: Narratives for shared socioeconomic pathways describing world futures in the 21 $1^{\text {st }}$ century, „Global Environ. Change” 2015, DOI: 10.1016/j.gloenvcha.2015.01.004.

Piniewski M. i in., Climate Change and Agricultural Development: Adapting Polish Agriculture to Reduce Future Nutrient Loads in a Coastal Watershed, „Ambio” 2014, vol. 43, no. 5, s. 644-660.

Piniewski M., Okruszko T., Acreman M.C., Environmental water quantity projections under market-driven and sustainability-driven future scenarios in the Narew basin, Poland, „Hydrological Sciences Journal” 2014, DOI: 10.1080/02626667.2014.888068.

Potting J., Bakkes J. (eds.), The GEO-3 Scenarios 2002-2032: Quantification and analysis of environmental impacts. UNEP/DEWA/RS.03-4 and RIVM 402001022, UNEP/RIVM, 2004.

Rounsevell M.D.A, Metzge M.J., Developing qualitative scenario storylines for environmental change assessment, „Wiley Interdisciplinary Reviews: Climate Change” 2010, vol. 1, no. 4.

Sterrenberg L. i in., Transition thinking and System Innovation. Theoretical notions and application, Pioneers into Practice Mentoring Programme, Climate-KIC, Netherlands 2014.

Strategiczny plan adaptacji dla sektorów i obszarów wrażliwych na zmiany klimatu do roku 2020 z perspektywą do 2030, Warszawa 2013.

Vliet van M. i in., Description of methods, their goals and their possible use in SCENES scenario development, Deliverable 2.1, Wageningen University, Wageningen 2007.

Zhovtonog O. i in., New planning technique to master the future of water on local and regional level in Ukraine, „Journal of Water and Climate Change” 2011, vol. 2, no. 2-3. 
www.eea.europa.eu/themes/scenarios/prelude (dostęp: 1.06.2016).

http://fortress-project.eu (dostęp: 1.06.2016).

www.gsg.org (dostęp: 1.06.2016).

www.ismb.it/en/node/2034 (dostęp: 1.06.2016).

www.mars-project.eu (dostęp: 1.06.2016).

www.sicmaproject.eu (dostęp: 1.06.2016).

\section{Streszczenie}

Celem artykułu jest prezentacja metody opracowywania scenariuszy wspomagających podejmowanie strategicznych decyzji w sektorze gospodarki wodnej, z uwzględnieniem zmian klimatycznych, w relacji do innych metod scenariuszowych tego typu, aby omówić proces tworzenia scenariuszy, ich użyteczność i możliwe zastosowania, a także słabe i mocne strony procesu pod kątem efektywnego stosowania metod scenariuszowych w przyszłości. Przestawiono uzasadnienie potrzeby stosowania tych metod i ich użyteczność. Dokonano przeglądu i klasyfikacji implementowanych na świecie i w Polsce metod scenariuszowych dotyczących strategicznych kwestii rozwojowych sektora gospodarki wodnej, z uwzględnieniem zmian klimatycznych na bazie wybranych projektów, w których zastosowano takie metody. Omówiono proces tworzenia scenariuszy, zidentyfikowano jego słabe i mocne strony oraz przedstawiono rekomendacje dla efektywnego stosowania metod scenariuszowych w przyszłości.

Slowa kluczowe: gospodarka wodna, scenariusze, metody, strategie 